\title{
Strategi Pengembangan dan Keberlanjutan Usahatani Aren melalui Penguatan Jiwa Kewirausahaan di Salawu Kabupaten Tasikmalaya
}

\author{
Yaya Sunarya ${ }^{1}$ \\ Candra Nuraini ${ }^{2}$ \\ Nur Arifah Qurota 'Ayunin ${ }^{3}$ \\ 1,2,3Fakultas Pertanian, Universitas Siliwangi \\ email: candranuraini@unsil.ac.id \\ Diterima: November 2020; Disetujui: April 2021; Dipublish: April 2021
}

\begin{abstract}
Abstrak
Usahatani gula aren di Kabupaten Salawu memiliki potensi ekspor yang tinggi. Namun perkembangan dan keberlanjutan usahatani menghadapi berbagai permasalahan yang kompleks. Strategi pengembangan dan keberlanjutan sebuah usahatani dapat diidentifikasi dari orientasi dan karakter kewirausahaan petani. Tujuan penelitian ini adalah menganalisis sikap dan orientasi kewirausahaan terhadap pengembangan dan strategi keberlanjutan usahatani gula aren di Kecamatan Salawu Kabupaten Tasikmalaya. Metode yang digunakan adalah SWOT (Strengths, Weaknesses, Opportunities, dan Threats). Penelitian dilakukan mulai Juli hingga Oktober 2020. Responden penelitian berjumlah 40 orang yang terdiri dari petani dan pengrajin gula aren yang tergabung dalam UKM Sirin dan Asosiasi Waringin Sari. Proses pengambilan data menggunakan kuesioner dan diskusi aktif pada kegiatan FGD (Focus Group Discussion). Hasil penelitian menunjukkan bahwa karakter kewirausahaan petani dan pengrajin pada faktor internal yang menjadi kekuatan yaitu sikap kerja keras, ketekunan, dan sikap menghadapi resiko, sedangkan karakter kewirausahaan yang masih menjadi kelemahan pelaku usaha tani yaitu inovasi, inisiatif, manajemen perencanaan, dan pemasaran. Sikap kerja keras pelaku usahatani adalah kemauan dan kedisiplinan dalam menjalankan usahatani. Selain itu, petani dan pengrajin gula aren berani menghadapi risiko dari sistem budidaya organik yang diterapkan. Strategi yang dapat digunakan petani dan pengrajin gula aren setelah menggabungkan faktor internal dan eksternal untuk menjamin keberlanjutan usahatani di Kecamatan Kawalu adalah offensive strategy.
\end{abstract}

Kata Kunci : Aren, Kewirausahaan, SWOT

\begin{abstract}
Palm sugar farming in Salawu Regency has high export potential. However, the development and sustainability of farming face various complex problems. The strategy for the development and sustainability of a farm can identify from the farmers' orientation and entrepreneurial character. The purpose of this study was to analyze entrepreneurial attitudes and orientation towards the development and sustainability strategy of palm sugar farming in Salawu District, Tasikmalaya Regency. The method used is SWOT (Strengths, Weaknesses, Opportunities, and Threats). The research conducted from July to October 2020. Forty respondents consisted of palm sugar farmers and artisans who are members of the Sirin UKM and the Waringin Sari Association. The process of collecting data using a questionnaire and active discussion in the FGD (Focus Group Discussion) activity. The results showed that farmers and artisans' entrepreneurial character on internal factors became their strengths, namely hard work, persistence, and risk-facing attitudes. In contrast, entrepreneurial characters that were still the weaknesses of farmers were innovation, initiative, planning management, and marketing. The hard work attitude of the farming actors is willingness and discipline in running farming. Besides, palm sugar farmers and artisans dare to face the risks from the organic cultivation system that is applied. The strategy that farmers and palm
\end{abstract}


sugar artisans can use after combining internal and external factors to ensure the sustainability of farming in Kawalu District is offensive.

\section{Key Words : Palm Sugar, Entrepreneurship, SWOT}

\section{PENDAHULUAN}

Pembangunan ekonomi nasional dapat dilakukan melalui optimalisasi pemberdayaan Usaha Mikro, Kecil, dan Menengah (UMKM). Sektor UMKM dapat memberikan dampak pada peningkatan kesejahteraan dan pengentasan kemiskinan melalui pemanfaatan kearifan lokal yang tidak bergantung pada impor. Penyerapan tenaga kerja dan peningkatan pendapatan masyarakat merupakan kontribusi positif dari berdirinya UMKM. Berdasarkan hasil analisis yang dilakukan Wibawa \& Anggitaria (2019), UMKM dapat mengurangi pengangguran seiring dengan peningkatan produksi. Salah satu UMKM yang ada di Kecamatan Salawu Kota Tasikmalaya adalah UKM Sirin. UKM Sirin merupakan perkumpulan petani dan pengrajin gula aren yang diolah menjadi gula semut.

Petani anggota UKM Sirin telah lama melakukan budidaya dan memproduksi gula semut meskipun dengan berbagai keterbatasan. Kendala yang dihadapi oleh petani yaitu budidaya pohon aren yang umumnya dengan teknik generatif, sehingga bergantung pada pohon aren yang telah tumbuh di masa sebelumnya. Pohon yang sudah ada tersebut memiliki produktifitas yang selalu menurun. Teknologi pengolahan yang digunakan petani dan pengrajin UKM Sirin cenderung masih rendah dengan peralatan sederhana dan tidak berorientasi pada pasar. Hal tersebut membuat petani sulit dalam proses pengembangan kualitas produk, sehingga gula aren atau gula semut hanya dibeli dengan harga rendah. Meskipun demikian, petani dan perajin masih berusaha mempertahankan produksi gula aren secara turun temurun dan berupaya mengembangkan lokasi menjadi sentra gula aren. Petani dan perajin selalu berusaha memperbaiki kualitas produk dan manajemen organisasi UKM supaya dapat meningkatkan daya saing usaha.

Petani dan pengrajin yang memiliki dasar perilaku kewirausahaan dapat mengatur bisnis lebih baik, inovatif, kreatif dan memiliki perspektif meraih pencapaian. Suatu bisnis dapat bertahan di pasarnya jika pelaku bisnis memiliki kompetensi kewirausahaan (Wakhidati et al. 2020). Selain itu, petani yang memiliki jiwa kewirausahaan akan lebih percaya diri terhadap kemampuan yang dimiliki, keterampilan memperluas jaringan sosial, dan memanfaatkan peluang. Petani akan cenderung memiliki keinginan untuk membuka bisnis baru disamping berupaya untuk memenuhi kebutuhan hidupnya (Arafat et al. 2018). Petani dan pengrajin di UKM Sirin Kecamatan Salawu terus berusaha untuk meningkatkan kompetensi dalam kewirausahaan.

Kinerja UMKM juga dapat dipengaruhi oleh orientasi kewirausahaan karena perubahan permintaan pasar dapat direspon dengan baik oleh UMKM dan inovasi produk (Asad et al. 2020); (Chege \& Wang 2020). Sher et al. (2019) mengkategorikan 
orientasi kewirausahaan meliputi kemampuan mengikuti pasar, sikap terhadap risiko, dan kemampuan yang proaktif untuk menunjang keberhasilan melakukan green farming. Dengan demikian kemampuan dalam aktivitas kewirausahaan dapat mendukung pertumbuhan dan kontinuitas bisnis. Aktivitas kewirausahaan dalam hal kemandirian finansial dapat diperoleh melalui kerja keras dan berani mengambil risiko (Morris et al. 2017).

Peningkatan kesejahteraan dan perluasan pasar merupakan tujuan yang dapat dicapai dengan kegigihan dan ketekunan dalam mengelola bahan baku lokal aren. Adanya kemajuan pembentukan asosiasi atau organisasi merupakan salah satu cerminan orientasi kewirausahaan (Militaru et al. 2015). Kegigihan petani sebagai individu dalam menjalankan usaha tani merupakan upaya untuk menyelesaikan pekerjaan dengan nilai biaya sebagai sebuah pengorbanan. Dengan adanya jiwa kewirausahaan, petani akan memiliki komitmen yang tinggi terhadap pekerjaannya. Komitmen dalam menjalankan bisnis akan membentuk rasa tanggung jawab pada diri petani untuk memberikan produk dan jasa yang terbaik guna memenuhi permintaan konsumen (Kagbu 2018). Adapun keunggulan anggota UKM Sirin di Kecamatan Salawu yaitu kegigihan petani dan pengrajin dalam mempertahankan sistem organik dalam budidaya dan pengolahan, meskipun penggunaan alat tradisional dapat menjadi hambatan dalam memperluas pasar gula aren di pasar domestik dan global. Oleh karena itu, perlu dilakukan penelitian terkait strategi keberlanjutan budidaya dan pengolahan gula aren dengan mempertahankan sistem organik melalui penguatan jiwa kewirausahaan pada pelaku bisnis.

Pentingnya pengembangan kewirausahaan lingkungan organik dapat mendukung kesejahteraan dan keberlanjutan kelestarian lingkungan (Ivanova et al. 2018). Sebab orientasi kewirausahaan sangat mendukung keberlanjutan lingkungan yang terdiri dari sumber daya manusia dan keterlibatan komunitas (Ayuso \& Navarrete-Báez 2018). Keberlanjutan dalam usaha tani yang di pengaruhi oleh perilaku kewirausahaan menggunakan Theory of Planned Behaviour menunjukkan bahwa niat seseorang dipengaruhi oleh keyakinan sekelilingnya atau tidak adanya faktor yang menfasilitasi sehingga menghambat keyakinan. Keyakinan ini mungkin didasarkan pada pengalaman masa lalu atau mengamati orang lain dalam komunitas (Aliabadi et al. 2020). Adapun keterbaharuan penelitian ini yaitu penggunaan Theory of Planned Behaviour untuk melakukan pengukuran terhadap sikap dan orientasi kewirausahaan yang berkaitan dengan strategi pengembangan dan keberlanjutan usahatani gula aren.

Penelitian ini bertujuan untuk menganalisis sikap dan orientasi kewirausahaan pada strategi pengembangan dan keberlanjutan usahatani gula aren di Kecamatan Salawu Kabupaten Tasikmalaya. Keteguhan dalam mengelola jiwa wirausaha petani dan pengrajin akan mendorong individu 
agar mampu bertahan dengan kekuatan tradisional dan berupaya memperbaiki kondisi untuk meningkatkan kualitas produk.

\section{METODE PENELITIAN}

Jenis penelitian yaitu deskriptif kualitatif menggunakan kuesioner, sehingga dapat diperoleh informasi secara mendalam dan tanggapan yang komprehensif. Penelitian ini dilakukan di Desa Neglasari Kecamatan Salawu. Penentuan lokasi penelitian dengan purposive atau sengaja dengan pertimbangan lokasi tersebut merupakan sentra aren potensial di Tasikmalaya. Penelitian dilakukan pada bulan Juli sampai Oktober 2020. Penelitian dilakukan pada seluruh populasi yaitu 40 pelaku usahatani gula aren yang terdiri dari petani dan pengrajin yang tergabung dalam UKM Sirin dan Asosiasi Waringin Sari. Keseluruhan responden telah mengikuti Focus Group Discussion (FGD) dengan perwakilan dari Dinas Pertanian, Dinas Perdagangan dan Koperasi, Kecamatan, dan Kelurahan.

Metode analisis yang digunakan adalah metode Strengths-WeaknessesOpportunities-Threats (SWOT) InternalEksternal Factor Evaluation (IFE-EFE). Internal Factor merupakan faktor yang terkait Strength dan Weaknes, sedangkan Eksternal Faktor terdiri dari Opportunity dan Thread. Audit internal terdiri dari manajemen, pemasaran, keuangan atau finansial, proses produksi, dan riset, sedangkan audit eksternal meliputi kondisi perekonomian, sosial dan budaya, demografi, teknologi, dan persaingan (David \& David 2017).
Strengths-Weaknesses-OpportunitiesThreats (SWOT) dibuat dengan langkahlangkah sebagai berikut :

1. Mengidentifikasi

kekuatan (strengths) internal

2. Mengidentifikasi kelemahan (weaknesses) internal

3. Mengidentifikasi peluang (opportunities) eksternal

4. Mengidentifikasi ancaman (threats) eksternal

5. Mencocokkan strengths dengan opportunities, sehingga menghasilkan strategi SO

6. Mencocokkan weaknesses dengan opportunities, sehingga menghasilkan strategi WO

7. Mencocokkan strengths dengan threats, sehingga menghasilkan strategi ST

8. Mencocokkan weaknesses dengan threats, sehingga menghasilkan strategi WT

Total skor dalam matriks evaluasi faktor internal dan eksternal miliki range 1 sampai 4 dengan rata-rata 2,5. Total skor tertimbang di bawah 2,5 mencirikan organisasi yang lemah secara internal, sedangkan skor di atas 2,5 menunjukkan posisi internal yang kuat (David 2017). Jika nilai EFE kurang dari 2,5 maka strategi yang digunakan tidak bekerja dengan baik dalam menangkap dan memanfaatkan peluang serta menanggulangi kelemahan (Mehbodi et al. 2018).

Analisis SWOT terdiri dari InternalExternal (IE) Matrix yang meliputi offensive strategy, adjust strategy, reactive strategy, dan defensive strategy. Dalam menerapkan strategi offensive 
(SO), organisasi dapat memanfaatkan peluang eksternal dengan menggunakan kekuatan internal (Banihashemi \& Rejaei 2016). Interaksi yang kuat antara kelemahan dan ancaman (WT) dapat dianggap sebagai peringatan potensial dan saran untuk digunakan strategi pertahanan (defensive strategies). Hubungan yang kuat antara kekuatan dan ancaman (ST) dapat memungkinkan penggunaan strategi yang beragam (diverse strategies), sedangkan interaksi antara kelemahan dan peluang (WO) dianalisis sebagai potensi untuk menggunakan strategi tinjauan atau ikhtisar (review or overview strategies) (Ghorbani et al. 2015).

Matriks IFE dan EFE digunakan untuk mengevaluasi lingkungan internal dan eksternal dan identifikasi peluang dan ancaman. Dalam menyusun matriks IFE dan EFE, terlebih dahulu mengidentifikasi faktor-faktor yang ada di lingkungan usahatani, penentuan bobot, rating, skor tertimbang dan skor tertimbang total.

\section{Penentuan Bobot}

Setelah mengidentifikasi faktor internal dan eksternal utama, setiap faktor kunci dari kriteria low importance sampai high importance diberikan bobot mulai 0,0 sampai 1,0 . Penentuan bobot mencerminkan seberapa penting faktor bagi usahatani. Masing-masing faktor diberikan bobot dan keseluruhan jumlah bobot adalah 1,0.

\section{Penentuan Rating}

Penentuan rating didasarkan pada faktor internal dan eksternal yaitu kemampuan usahatani dalam memberikan tanggapan. Matriks EFE mengacu pada tingkat efektivitas merespon peluang dan ancaman dari luar usahatani. Perubahan faktor eksternal tidak dapat dikendalikan oleh pelaku usaha atau organisasi, tetapi dapat dilakukan antisipasi dan adaptasi pada perubahan tersebut. Matriks IFE mengacu pada manajemen internal pelaku usaha atau organisasi yaitu mengoptimalkan kelebihan pada kekuatan yang dimiliki dan memanajemen kekurangan atau kelemahan agar dapat dihilangkan, diminimalisir, atau dapat dikelola agar tidak berdampak negatif pada usahatani. Angka pada penentuan rating yaitu bernilai dari 1 sampai 4 . Nilai 4 merupakan faktor yang paling kuat, sedangkan nilai mendekati 1 merupakan faktor kelemahan.

3. Skor Tertimbang dan Tertimbang Total

Setelah memilih faktor kunci yang memiliki pengaruh dominan pada usahatani, nilai dari bobot dikalikan dengan rating. Total skor tertimbang merupakan jumlah dari semua nilai tertimbang individu. Skor rata-rata yaitu 2,5. Jika faktor eksternal memiliki nilai lebih besar dibanding faktor internal, maka strategi secara eksternal dapat digunakan untuk memperoleh peluang dan mengantisipasi atau bertahan terhadap ancaman dari luar. Sebaliknya, jika faktor internal bernilai lebih besar dibanding faktor pada strategi internal maka strategi dapat dimanfaatkan untuk meningkatkan sumber daya yang ada sebagai kekuatan dan mengidentifikasi kelemahan organisasi 
untuk dilakukan perbaikan maupun upaya mengelola kelemahan tersebut.

\section{HASIL DAN PEMBAHASAN}

Orientasi jiwa kewirausahaan pada suatu bisnis dengan keterlibatan anggota keluarga dalam suatu usaha, dapat mengurangi dampak negatif dari pengambilan risiko dan pertumbuhan bisnis (Casillas \& Moreno 2010). Hal ini terkait dengan keberlanjutan usahatani gula aren yang bersifat turun-temurun dalam suatu keluarga sehingga dapat menentukan strategi dalam jangka panjang dan peraturan yang esensial untuk usahatani yang telah lama ditekuni. Pertanian yang identik pada lingkungan pedesaan dengan motivasi diri yang rendah menjadi kendala dalam mengupayakan inisiatif kewirausahaan dalam memperoleh profit. Faktor utama yang dapat menghambat pengembangan kewirausahaan sektor pertanian di pedesaan yaitu keterbatasan modal finansial, kurangnya sikap kerja keras, dan tidak adanya renumerasi harga dalam proses produksi. Faktor penghambat moderat yaitu kurang pupuk organik, pendidikan yang rendah, dan jaringan pasar yang terbatas (Choudhury \& Easwaran 2019).

Hasil wawancara dan FGD dengan petani dan pengrajin serta perwakilan dinas terkait di Kecamatan Salawu dapat diidentifikasi menggunakan matriks IFE dan EFE. Berdasarkan infromasi dari Balai Pengkajian Teknologi Pertanian (BPTP) Kecamatan Salawu tahun 2019, potensi aren yang ada di lokasi terdiri 4.802 pohon aren muda, 3.432 pohon aren tua, dan 453 pohon sadap dengan rata-rata produksi mencapai 99,72 kg per tahun. Faktor internal yang ada pada usahatani aren terkait dengan sikap kewirausahaan pada pelaku pengolahan aren terutama petani dan pengrajin aren, sedangkan faktor eksternal mengarah pada kondisi perekonomian dan pesaing.

Penelitian sebelumnya dilakukan oleh Arifin \& Sulistio (2017) untuk melihat pentingnya preferensi pemangku kepentingan dalam menyediakan jalur sepeda di Provinsi Jawa Timur. Hasil penelitian menunjukkan bahwa analisis faktor internal meliputi sumber daya manusia, pemasaran, dan finansial, sedangkan faktor eksternal meliputi kondisi sosial-ekonomi, demografi, peraturan hukum, teknologi dan kebijakan pemerintah. Sementara itu faktor sumber daya manusia memiliki pengaruh yang penting pada preferensi karena terkait pada karakter individu . Kompetensi sumber daya manusia dianggap memiliki pengaruh penting terhadap pengembangan suatu institusi (Hashemi et al. 2017). Sumber daya manusia mempunyai peran penting dalam mewujudkan budaya wirausaha dan inovasi. Sumber daya manusia yang tersedia merupakan aset potensial dan perlu dilakukan pengembangan kemampuan individu untuk menghasilkan budaya kewirausahaan (entreprenurial behaviour). Sumber daya manusia dapat melakukan perluasan jaringan untuk meningkatkan budaya kewirausahaan dengan adanya pertukaran informasi dan pengalaman (Khoshmaram et al. 2018).

Hasil total skor pada masing-masing indikator kekuatan dan kelemahan dapat dilihat pada Tabel 1. Petani dan pengrajin 
aren di Kecamatan Salawu dalam menjalankan usahatani aren telah memiliki sikap kerja keras dengan skor mencapai 0,72 . Hal ini dapat ditunjukkan dari ketekunan dan kegigihan dalam memperoleh bahan baku dan mampu melewati proses pengolahan yang membutuhkan waktu lama untuk menjadi gula semut. Petani rata-rata memiliki pengalaman lebih dari 20 tahun. Petani disiplin dalam menerapkan jadwal penyadapan pada pagi hari pukul sebelum matahari terbit dan segera mengolah air nira mulai dari pengayakan sampai pemasakan. Proses pemasakan yang masih tradisional dengan pengadukan menggunakan kayu selama 6 jam sampai mengering. Petani dan pengrajin mampu menghasilkan kualitas aren dan gula semut yang kering tanpa bahan pengawet, sehingga hal ini menjadi peluang keunggulan produk dengan skor 0,45 .

Tabel 1. Analisis Matriks Internal Factor Evaluation (IFE)

\begin{tabular}{|c|c|c|c|c|}
\hline No. & Faktor Internal & Bobot & Rating & $\begin{array}{l}\text { Total } \\
\text { Skor }\end{array}$ \\
\hline \multicolumn{5}{|c|}{ KEKUATAN } \\
\hline S1 & $\begin{array}{l}\text { Tekun menerapkan sistem organik untuk keberlanjutan dan } \\
\text { kelestarian }\end{array}$ & 0,15 & 3 & 0,45 \\
\hline S2 & Ketersediaan sumber daya alam dan kearifan lokal & 0,1 & 2 & 0,20 \\
\hline S3 & Berani menghadapi risiko & 0,09 & 3 & 0,27 \\
\hline S4 & Memiliki sikap kerja keras & 0,18 & 4 & 0,72 \\
\hline \multicolumn{5}{|c|}{ KELEMAHAN } \\
\hline W1 & Tidak memahami ekspansi pasar & 0,16 & 2 & 0,32 \\
\hline W2 & Softskill komunikasi & 0,07 & 2 & 0,14 \\
\hline W3 & Belum melakukan inovasi dan adopsi teknologi & 0,11 & 3 & 0,33 \\
\hline \multirow[t]{2}{*}{ W4 } & Lemahnya inisiatif dan perencanaan & 0,14 & 3 & 0,42 \\
\hline & Total & 1,00 & & 2,85 \\
\hline
\end{tabular}

Sumber : Data Primer, 2020

Sikap pasif petani dan pengrajin yang menjadikan usahatani gula aren menjadi subsisten atau hanya terbatas pada pemenuhan kebutuhan keluarga. Skor 0,42 yang menunjukkan inisiatif dan perencanaan untuk menjadi lebih profitable pada usahatani masih rendah. Perencanaan yang belum dilakukan meliputi perencanaan keuangan, pemasaran, manajemen sumber daya manusia, dan sumber daya alam yang digunakan sebagai bahan baku. Pelaku usaha gula aren sebagian besar cenderung pasif karena faktor umur yang sudah memasuki usia lansia sehingga sangat sulit untuk mengakses teknologi dan informasi.

Keterbatasan informasi tersebut membuat petani kurang memahami strategi komersialisasi pasar sehingga membuat petani dan pengrajin belum

melakukan ekspansi pasar. Motivasi komersialisasi yang rendah pada petani dan pengrajin terlihat pada kreatifitas dalam menciptakan inovasi produk dan bisnis yang terdiversifikasi. Saat ini produk tersedia dalam bentuk gula semut atau serbuk dan gula padat atau gula balok dengan kemasan yang sangat sederhana menggunakan plastik dan 
daun. Sikap kewirausahaan salah satunya tercermin dalam melakukan inovasi produk dan adopsi teknologi. Inovasi yang rendah pada diri petani dan pengrajin menjadi kendala dalam meningkatkan nilai tambah produk gula aren. Pada proses budidaya juga belum dilakukan inovasi teknologi perkembangan benih. Selain itu, pada pengolahan nira belum menerapkan teknologi pengendalian $\mathrm{pH}$ menggunakan bahan-bahan yang dapat menjaga $\mathrm{pH}$ aren tetap stabil.

$$
\text { Analisis faktor eksternal }
$$
menggunakan matriks EFE dapat dilihat pada Tabel 2. Gula semut aren di Kecamatan Salawu memiliki banyak potensi untuk dikembangkan karena memiliki beberapa peluang. Peluang eksternal adalah potensi menjadi produk ekspor karena menurut Kementerian Perdagangan selama periode 2012 - 2016 rata-rata ekspor meningkat 6\% per tahun dan Indonesia termasuk 10 besar eksportir gula semut dunia meskipun baru mencapai pangsa pasar 3\% (Sahat 2017) al ini dipengaruhi karena trend gaya hidup sehat dengan konsumsi alternatif gula semut yang rendah glikemik.

Peluang di lingkungan sentra yaitu adanya perencanaan wilayah menjadi agrowisata dengan skor 0,34 dan berkembangnya kuliner kafe kopi dengan skor 0,24 menjadi daya dukung dan peluang gula semut menjadi produk yang potensial untuk berkembang. Adanya pengembangan kawasan agrowisata menjadi peluang dalam mengembangkan diversifikasi ekonomi melalui pendapatan non-farm. Agrowisata juga dianggap sebagai diverisifikasi dalam memperoleh peluang bisnis (Phelan \& Sharpley 2011). Rencana pembuatan agrowisata di Kecamatan Salawu mulai muncul dan dibicarakan oleh pihak-pihak terkait.

Tabel 2. Analisa Matriks Eksternal Factor Evaluation (EFE)

\begin{tabular}{llrrr}
\hline No. & \multicolumn{1}{c}{ Faktor Eksternal } & Bobot & $\begin{array}{c}\text { Rating } \\
\text { PELUANG }\end{array}$ & $\begin{array}{c}\text { Total } \\
\text { Skor }\end{array}$ \\
\hline O1 & Pengembangan kawasan agrowisata & 0,17 & 2 & 0,34 \\
O2 & Potensi pasar ekspor produk organik & 0,14 & 4 & 0,56 \\
O3 & Dukungan pemerintah pada organisasi & 0,07 & 3 & 0,21 \\
O4 Kafe atau kedai kopi menjadi trend kuliner & 0,12 & 2 & 0,24 \\
ANCAMAN & & & \\
T1 $\quad$ Tengkulak yang dapat menurunkan daya tawar petani & 0,12 & 2 & 0,24 \\
T2 $\quad$ Perusahaan lain membuat produk yang sama & 0,11 & 2 & 0,22 \\
T3 $\quad$ Regenerasi petani & 0,1 & 4 & 0,40 \\
T4 Produk belum tersertifikasi & 0,17 & 3 & 0,51 \\
\hline \multicolumn{1}{c}{ Total } & 1,00 & & 2,72 \\
\hline
\end{tabular}

Sumber : Data Primer, 2020

Pada matriks EFE Tabel 2 ancaman keberlanjutan usahatani aren yang menjadi perhatian utama dengan skor 0,51 adalah produk yang belum tersertifikasi. Hal ini menyebabkan produk dipersepsikan oleh konsumen sebagai produk yang kurang berkualitas dan keinginan konsumen untuk membeli menjadi rendah. Faktor lain yang cukup mengancam keberlanjutan usahatani aren 
di Kecamatan Salawu adalah regenerasi petani dengan skor mencapai 0,40. Hingga saat ini, petani aren dan pengrajin didominasi petani yang sudah tua, sedangkan generasi muda kurang berminat untuk menjadi petani karena pekerjaan lain seperti buruh atau staff perkantoran di kota lebih menarik dan menjanjikan pendapatan tetap. Petani dan pengrajin gula aren di Kecamatan Salawu belum memiliki daya tawar pada produk yang dihasilkan, sehingga petani dan pengrajin masih sebagai market follower. Petani dan pengrajin tidak dapat menawarkan produk dengan harga tinggi di pasar, sehingga pemasaran gula semut aren hanya terbatas pada lingkup yang kecil.

Total skor matriks IFE pada Tabel 1 yaitu 2,85, sedangkan total skor matriks EFE pada Tabel 2 yaitu 2,72. Matriks IFE yang lebih besar dari 2,5 menunjukkan bahwa faktor internal pada usahatani gula semut aren menunjukkan posisi yang kuat dimana kekuatan yang dimiliki dapat mengatasi kelemahan yang ada. Demikian dengan EFE, skor yang lebih dari 2,5 menunjukkan bahwa peluang pada faktor eksternal dapat berpotensi untuk dimanfaatkan. Dari analisis matriks IFE dan EFE dapat diperoleh strategi sebagai berikut:

\section{a. Strategi S-O (Strength-Opportunity)}

Usahatani gula aren di Kecamatan

Salawu dapat dikembangkan dengan adanya kerja keras petani dan pengrajin yang bekerja setiap hari dari pagi hingga petang dan antusias dalam mengikuti pelatihan atau pengarahan dari Akademisi, BPP dan dinas terkait. Motivasi dan kerja keras dapat menjaga dan mempertahankan penggunaan sistem organik pada olahan aren agar menjadi produk premium yang berkualitas serta mampu bersaing di pasar baik local maupun global. Upaya perluasan pasar tersebut membutuhkan kegigihan dalam berusaha dan pantang menyerah untuk terus mencoba. Sebuah kegigihan merupakan salah satu modal strategis (Hudson 2010). Kegigihan dalam mengakses pasar juga dipengaruhi oleh kemampuan keterampilan dalam berkomunikasi. Petani sangat perlu meningkatkan keterampilan berkomunikasi untuk meningkatkan jiwa kewirausahaan. Sebab komunikasi menjadi syarat penting dalam melakukan akses pasar. Sedangkan, akses informasi pasar merupakan kemampuan sosial ekonomi yang dapat memperluas jaringan untuk pemasaran produk (Naminse \& Zhuang 2018).

\section{b. Strategi S-T (Strength-Threats)}

Petani dan pengrajin perlu memperkuat manajemen organisasi dan mempertahakan sistem organik untuk keberlanjutan usahatani. Manajemen organisasi merupakan suatu asosiasi atau wadah untuk mengatur strategi peningkatan kualitas produk dan regenerasi. Regenerasi dalam suatu keluarga diperlukan dalam setiap aktivitas pertanian mulai dari pencarian bahan baku, pengolahan, dan pemasaran untuk pemenuhan kebutuhan hidup dan perkembangan usahatani (Fitz-Koch et al. 2018). Regenerasi merupakan salah satu bentuk nyata manajemen sumber daya manusia dalam menjalankan usahatani gula aren. Dengan adanya 
manajemen sumber daya manusia maka dapat dilakukan regenerasi penerus usahatani dengan job description dan bidang yang jelas serta tepat. Dengan demikian, akses pada administrasi produk pada sertifikasi organik, PIRT, dan perijinan Halal MUI dapat diperoleh.

\section{c. Strategi W-O (Weaknesses- Opportunities)}

Koordinasi pada petani dan perajin gula semut yang masih lemah dapat diperbaiki melalui adanya asosiasi. Koordinasi dapat dilakukan untuk merumuskan perencanaan kegiatan, strategi pemasaran dan manajemen kualitas produk. Dengan adanya organisasi atau asosiasi, akan lebih mudah dalam mengakses permodalan dan perluasan pasar serta pengembangan wilayah untuk kawasan agrowisata. Inisiatif yang kurang pada petani dan perajin dapat ditingkatkan melalui penguatan manajemen organisasi untuk melakukan studi banding ke sentra aren di wilayah lain yang lebih maju skala usahanya.

d. Strategi W-T (Weaknesses-Threats)

Jiwa kewirausahaan pada petani dapat berkontribusi terhadap pengurangan kemiskinan. Petani dapat melakukan upaya diversifikasi dalam upaya mengurangi risiko dan menambah peluang pendapatan (Naminse \& Zhuang 2018). Dengan demikian, karakter jiwa kewirausahaan dapat menjadi penentu keberhasilan suatu usahatani karena berkaitan langsung dengan perilaku pelaku usahatani. Petani dan pengrajin yang tidak kurang inisiatif dan inovatif dapat menjadi kendala dalam memperbaiki kekurangan produk.
Upaya untuk meningkatkan inisiatif pada diri petani dan pengrajin dapat melalui pelatihan dan penyuluhan dengan memberi pengetahuan dan pengalaman sukses yang inspiratif. Dengan demikian, semangat dan pengembangan diri dapat dengan sendirinya muncul pada diri petani dan pengrajin gula semut. Administrasi perijinan produk atau sertifikasi merupakan salah satu kendala untuk positioning dan ekspansi produk. Umur yang sudah tua dan keterbatasan informasi pada petani menjadi kendala dalam mengakses perijinan, sehingga pelatihan dan manajemen organisasi menajdi penting untuk meningkatkan inisiatif, inovasi, dan regenerasi usahatani gula semut aren. Peran penting generasi muda dalam pembangunan di perkotaan yang dapat berkontribusi menjadi kekuatan untuk meningkatkan efisiensi program (Shakerian et al. 2016).

Strategi yang dapat digunakan petani dan pengrajin gula aren setelah menggabungkan faktor internal dan eksternal untuk menjamin keberlanjutan usahatani di Kecamatan Kawalu adalah offensive strategy. Strategi ini merupakan upaya optimalisasi kemampuan pelaku usahatani aren untuk meningkatkan kualitas produk. Produk aren di Kecamatan Salawu khususnya UMKM Sirin memiliki keunggulan bersifat organik dan murni. Selain meningkatkan kualitas produk, petani dan pengrajin gula aren harus meningkatkan ketekunan, pengetahuan, dan manajemen organisasi dalam perencanaan bisnis sehingga memenuhi persyaratan ekspor. 


\section{SIMPULAN}

Sikap dan orientasi kewirausahaan yang harus ditingkatkan pelaku usaha sebagai sebuah strategi pemanfaatan kekuatan dan peluang untuk mengembangkan usahatani gula aren yaitu sikap kerja keras, tekun atau gigih, dan berani mengambil resiko dengan menerapkan sistem organik untuk meningkatkan kualitas produk yang berorientasi pada pasar ekspor. Selain itu, sikap dan orientasi kewirausahaan yang mengarah pada strategi pemanfaatan kekuatan dan ancaman untuk menjaga keberlanjutan usahatani gula aren yaitu mengantisipasi persaingan produk subsitusi dan melakukan regenerasi pelaku usahatani. Adapun strategi yang dapat dilakukan petani dan pengrajin gula aren untuk melanjutkan usahatani adalah offensive strategy. Strategi ini merupakan upaya optimalisasi kemampuan pelaku usahatani aren untuk meningkatkan kualitas produk.

\section{UCAPAN TERIMAKASIH}

Kegiatan Pengabdian Kepada Masyarakat ini dapat dilaksanakan dengan baik atas kerjasama dengan berbagai pihak. Penulis mengucapkan terima kasih kepada Kementerian Riset dan Teknologi/Badan Riset dan Inovasi Nasional yang telah memberikah dana hibah dengan nomor kontrak 149/UN58.21/AM/2020 tanggal 1 April 2020, guna memfasilitasi seluruh rangkaian kegiatan pengabdian sehingga berjalan dengan lancar. Terimakasih juga disampaikan kepada LP2M-PMP Universitas Siliwangi, BPP Salawu, SKPD di Kabupaten Tasikmalaya, petani, pengrajin, dan pengusaha gula aren di Kecamatan Salawu.

\section{DAFTAR PUSTAKA}

Aliabadi V, Gholamrezai S, Ataei P. 2020. Rural people's intention to adopt sustainable water management by rainwater harvesting practices: Application of TPB and HBM models. Water Sci Technol Water Supply. 20(5):1847-1861.

Arafat MY, Saleem I, Dviwedi AK, Khan A. 2018. Determinants of agricultural entrepreneurship: a GEM data based study. Int Entrep Manag J. 16(1):345-370.

Arifin MZ, Sulistio H. 2017. The Policy and the Strategy of the Provision of Bicycle Lane in East Java, Indonesia. Open Sci J. 2(2):1-11.

Asad M, Chethiyar SDM, Ali A. 2020. Total Quality Management, Entrepreneurial Orientation, and Market Orientation: Moderating Effect of Environment on Performance of SMEs. Paradigms. 14(1):102-108.

Ayuso S, Navarrete-Báez FE. 2018. How Does Entrepreneurial and International Orientation Influence SMEs' Commitment to Sustainable Development? Empirical Evidence from Spain and Mexico. Corp Soc Responsib Environ Manag. 25(1):80-94.

Banihashemi SA, Rejaei Z. 2016. Assessment of Environmental Conditions and Internal Capabilities Affecting University Strategies (IFE, EFE, SWOT \& AHP Models). Int J Asian Soc Sci. 6(10):558-567.

Casillas JC, Moreno AM. 2010. The relationship between entrepreneurial orientation and growth: The moderating role of family involvement. Entrep Reg 
Dev. 22(3-4):265-291.

Chege SM, Wang D. 2020. The impact of entrepreneurs' environmental analysis strategy on organizational performance. J Rural Stud. 77(April 2019):113-125.

Choudhury K, Easwaran K. 2019. Agricultural entrepreneurship in Lower Brahmaputra Valley, Assam. J Glob Entrep Res. 9(1):2-13.

David FR. 2017. Strategic Management: A Competitve Advantage Approach. [place unknown].

David Fred R., David Forest R. 2017. Strategic Management: A Competitve Advantage Approach. England.

Fitz-Koch S, Nordqvist M, Carter S, Hunter E. 2018. Entrepreneurship in the agricultural sector: A literature review and future research opportunities. Entrep Theory Pract. 42(1):129-166.

Ghorbani A, Raufirad V, Rafiaani P, Azadi H. 2015. Ecotourism sustainable development strategies using SWOT and QSPM model: A case study of Kaji Namakzar Wetland, South Khorasan Province, Iran. Tour Manag Perspect. 16:290-297.

Hashemi SM, Samani FS, Shahbazi V. 2017. Strengths, Weaknesses, Opportunities and Threats (SWOT) Analysis and Strategic Planning for Iranian Language Institutions Development Ranking and Evaluating Students' University Selection Priorities Using Analytic Hierarchy Process (AHP) in an EFL Learnin. J Appl Linguist Lang Res. 4(2):139-149.

Hudson R. 2010. Resilient regions in an uncertain world: Wishful thinking or a practical reality? Cambridge J Reg Econ Soc. 3(1):11-25.

Ivanova N, Gotsulyak I, Rudaleva I, Markova S. 2018. Environmental entrepreneurship: theoretical aspects, development prospects in organic agriculture. 61(2018):296301.

Kagbu JH. 2018. Constraints to women farmers' entrepreneurial development in Nasarawa state, Nigeria. J Agric Ext. 22(1):44-54.

Khoshmaram M, Shiri N, Shinnar RS, Savari M. 2018. Environmental support and entrepreneurial behavior among Iranian farmers: The mediating roles of social and human capital. J Small Bus Manag. 58(5):1-19.

Mehbodi M, Yazdanpanah A, Alvaani J. 2018. the Impact of Strategic Factors of Waste Management on Environmental Protection in Kazeroon City in 2017. Univers J Pharm Res. 3(4):26-30.

Militaru G, Pollifroni M, Deselnicu DC. 2015. Rural Entrepreneurship Development. FAIMA Bus Manag J. 3(4):5-17.

Morris W, Henley A, Dowell D. 2017. Farm diversification, entrepreneurship and technology adoption: Analysis of upland farmers in Wales. J Rural Stud. 53(2017):132-143.

Naminse EY, Zhuang J. 2018. Does farmer entrepreneurship alleviate rural poverty in China? Evidence from guangxi province. PLoS One. 13(3):1-18.

Phelan C, Sharpley R. 2011. Exploring agritourism entrepreneurship in the UK. Tour Plan Dev. 8(2):121136.

Sahat SF. 2017. Peluang Ekspor Gula Semut. Kementrian Perdagang Republik Indones [Internet].:1-20. http://djpen.kemendag.go.id

Shakerian H, Dehnavi HD, Ghanad SB. 2016. The Implementation of the Hybrid Model SWOT-TOPSIS by 
Fuzzy Approach to Evaluate and Rank the Human Resources and Business Strategies in Organizations (Case Study: Road and Urban Development Organization in Yazd). Procedia Soc Behav Sci. 230(2016):307-316.

Sher A, Mazhar S, Zulfiqar F, Wang D, Li $X$. 2019. Green entrepreneurial farming: A dream or reality? J Clean
Prod. 220(2019):1131-1142.

Wakhidati YN, Sugiarto M, Aunurrohman H. 2020. Entrepreneur Behavior of Brolier Farmers in Banyumas. Anim Prod. 21(2):104.

Wibawa RR, Anggitaria NR. 2019. EQUILIBRIA PENDIDIKAN Jurnal Ilmiah Pendidikan Ekonomi. Equilibria Pendidilan. 4(5): 3646. 